\title{
Article
}

\section{Introduction to the special issue: The enactment of neoliberalism in the workplace: The degradation of the employment relationship}

Thomas, Pete, Mc Ardle, Louise and Saundry, Richard

Available at http://clok.uclan.ac.uk/30674/

Thomas, Pete, Mc Ardle, Louise ORCID: 0000-0003-0039-0814 and Saundry, Richard (2020) Introduction to the special issue: The enactment of neoliberalism in the workplace: The degradation of the employment relationship. Competition \& Change, 24 (2). pp. 105-113. ISSN 1024-5294

It is advisable to refer to the publisher's version if you intend to cite from the work. http://dx.doi.org/10.1177/1024529419882281

For more information about UCLan's research in this area go to http://www.uclan.ac.uk/researchgroups/ and search for <name of research Group>.

For information about Research generally at UCLan please go to http://www.uclan.ac.uk/research/

All outputs in CLoK are protected by Intellectual Property Rights law, including Copyright law. Copyright, IPR and Moral Rights for the works on this site are retained by the individual authors and/or other copyright owners. Terms and conditions for use of this material are defined in the policies page. 
Introduction to the special issue: The Enactment of Neoliberalism in the Workplace:

\title{
The Degradation of the Employment Relationship
}

Louise McArdle, Lancashire School of Business and Enterprise, University of Central Lancashire.

Dr Richard Saundry, Visiting Professor, Manchester Metropolitan University. Dr Pete Thomas, Department of Organisation, Work and Technology, Lancaster University.

\begin{abstract}
This article introduces readers to the special issue on 'the enactment of neoliberalism in the workplace'. We argue that contemporary developments such as zero-hours contracts, casualisation and platform work are part of a neoliberal regime of deregulation and flexibilization that renders employment precarious and work degraded. Thus, the degradation of work that Braverman wrote of should be extended to include aspects of the employment relationship, acknowledging the crucial relationship between the mode of employment and the experience of work. In short, we assert that the quality of work is intimately connected to the quality of employment. The neoliberal agenda is played out in and around organizations through management decisions on employment and work, which, in turn, have significant and complex connections to a range of wider social, economic and political issues, such as poverty, and welfare systems. The articles in our special issue explore and analyse several dimensions of the changes taking place and whilst present a rather gloomy view of contemporary work and employment they do demonstrate continued scope for resistance.
\end{abstract}

Keywords: neoliberalism, employment relations, quality of work, regulation, inequality 
In recent years, the notion of 'good work' has occupied an increasingly central place within policy debate, triggered by labour market fragmentation and apparent concern over the implications of job insecurity and pay inequality. Whilst the quality of jobs has been a longstanding concern of many academics, trade unionists, and employers, there seems to have been a resurgence of interest in the issue, with increasing reports and perceptions of a deterioration in the quality of jobs (Adamson and Roper, 2019; Kalleberg, 2016). Braverman explored the degradation of work in his influential book Labor and Monopoly Capital in which he examined the labour process through a 'concrete and historically specific analysis of technology and machinery on the one side and social relations on the other, and of the manner in which these two come together in existing societies' (1974: 17). In a situation in which 'The worker enters into the employment agreement because social conditions leave him or her no other way to make a living' (Braverman 1974: 53), he found the experience of work was deskilled and degraded by technology and management, as a result of the expansion of capital. Subsequently, the agenda for the study and critique of work has developed from the deskilling thesis to take in issues such as managerial control (Friedman, 1977; Burawoy, 1979), work intensification (Elger, 1991; Hassard et al., 2009; Granter et al., 2019) and surveillance and evaluation (Moore, 2018; Allan et al., 2019).

In this special issue, we wish to extend the scope of this tradition further by considering the employment relationship as well as the process of 'labouring' in employment; in short, we acknowledge the relationship between the mode of employment and the experience of work. It seems that a range of employment practices are being deployed in and around organizations that, for increasing numbers of people around the world, degrade their experience of work. A lengthy but incomplete list of practices might include zero-hours contracts, casualization, temporary contracts, platform work, increasing use of part-time workers, and 'selfemployment'. The results for some are precarity and job insecurity, in-work poverty and uncertainty over future employment that makes it difficult to make financial plans and thus impedes the ability to make longer-term life plans. The erosion of trade union organisation and 
collective regulation, and the weakening of employment regulation in some countries, could also be said to have degraded the employment and work by undercutting resistance.

These changes have been linked to a neoliberal phase of capitalism (Fabry and Sandbeck, 2019; Mirowski 2013; Styhre, 2014). Defining neoliberalism represents something of a challenge that has created a series of 'definition wars' (Bacevic, 2019), that stem in part from the ways in which the idea tends to cross academic disciplinary boundaries, thus generating a variety of conceptualisations and from the term's use in broader political discourse (Plehwe et al., 2006; Styhre, 2014). Nevertheless, we feel it necessary to offer a broad framing of neoliberalism for this special issue and to delineate what we see as its most pertinent features in relation to work and employment. Harvey's (2005: 2) definition represents an appropriate starting point: Neoliberalism is 'a theory of political economic practices that proposes that human well-being can best be advanced by liberating individual entrepreneurial freedoms and skills within an institutional framework characterized by strong private property rights, free markets, and free trade'. Harvey's (2005) subsequent critique examines the construction of political consent for neoliberalism and the role of the state in its variable enactment around the world, both of which are salient to the phenomena explored in this special issue.

More recently, Styhre (2014) has drawn on Wacquant (2009) and Griffin (2009) to outline the components of neoliberalism. Wacquant (2009) identifies four components: economic deregulation, welfare state devolution, a culture of individual responsibility and an active penal system. Griffin (2009) highlights four propositions: confidence in market mechanisms for resource distribution, a commitment to the private financing of public projects, deregulation that allows free trade and capital mobility, and the flexibilization of production. It is clear that some of these contextual factors have influenced contemporary work and employment through labour market structures and operations, however, the influence of broader cultural factors should also be acknowledged. Fleming (2017) makes clear the links between one influential strand of neoliberal thought, human capital theory (Becker, 1964; Schultz, 1961), and current 
employment and work practices. He argues that the assumptions that underpin human capital theory, foster the use of highly individualizing practices, such as self-employment, 'gig' work and 'on-demand' business models, and that this 'radical responsibilization' has many negative effects on personal and societal wellbeing.

Mirowski (2013: 92) draws our attention to 'everyday neoliberalism', and to the 'accretion of neoliberal attitudes, imaginaries, and practices that have come to inform everyday life in the first few decades of the new millennium'. Thus, we should consider the ways in which the idea of the entrepreneur have been enacted and experienced, how competition has become 'the primary virtue' (Mirowski, 2013: 92) and how the practices of employment have been influenced by this. Mirowski writes of the fragmentation of the neoliberal self within an economic context of downsizing and modernization, and of the necessity to be 'flexible in any and all respects' (2013: 108, original emphasis), that is, within and around work, and in and about employment. Drawing on ethnographies of work (Ehrenreich, 2005; Martin 1994; Urciuoli, 2008), he argues that 'those seeking employment must learn to regard themselves as a "bundle of skills" for which they bear sole responsibility', skills that are not only about craft or technical ability (where relevant) in the traditional sense, but also about 'life, ‘communication' or 'soft skills' (Mirowski, 2013: 110). These skills are focussed on being amenable to temporary alliances with others and being compliant with all forms of supervisory relationship, thus extending notions of flexibility, beyond function and availability for work, to the self and one's sense of self. As Thrift (2005: 34) puts it: 'the business organization must be made up of willing and willed subjects', but within a neoliberal employment regime they must also be willing to stand down, move on or, in neoliberal-speak, find opportunities for investment and attainment elsewhere. Much like the neoclassical conception of a firm as a bundle of contracts (Jensen and Meckling, 1976), the neoliberal self is 'a jumble of assets to be invested, nurtured, managed, and developed; but equally an offsetting inventory of liabilities to be pruned, outsourced, shorted, hedged against, and minimized' (Mirowski, 2013: 108). 
A range of opinion exists on the relative benefits and disadvantages of these changes and, as we mentioned at the outset, a significant debate on the nature and quality of work and employment has emerged in recent years. This generated a number of ways by which the quality of jobs can be evaluated (Adamson and Roper, 2019; Kalleberg, 2016), considering components of work and employment, such as pay, hours, job security, work life balance, and fairness (for example: Eurofound, 2017; Ghai, 2003). Kalleberg (2016) condenses the components into the following: economic compensation, job security and opportunities for advancement and the extent of control over one's own work and work schedules. 'Good work' has also entered the wider discourse about work and employment (Work Foundation, 2016), coming to prominence in the UK in Good Work: The Taylor Review of Modern Working Practices (Taylor et al., 2017). The report provoked a wide range of responses, reflecting the interests of different stakeholder groups in fairly predictable ways (Chartered Institute for Personnel and Development, 2018; Department for Business, Energy and Industrial Strategy, 2018; TUC, 2018a, 2018b, 2018c). Moreover, Taylor faced the problem that the very idea of good (or bad) work is itself contested (Adamson and Roper 2019; Kalleberg, 2016). This relates to basic issues, such as the definition of employment or work in a world with an increasing array of modes of employment and contract and also the extent to which any rights or regulations can be enforced (Kirk, 2017). Perhaps inevitably, in trying to deliver a politically acceptable policy agenda to an unapologetically neo-liberal UK government, Taylor's prescriptions failed to acknowledge the asymmetry of power within the employment relationship that constrains the ability of labour to defend or forge 'good work'. The nature of 'good work' rests not only on the quality of the work itself, but also on the employment context within which it takes place.

Trying to traverse the terrain of work and employment is difficult and we cannot hope to cover all aspects of job quality here. The Taylor Review (2017) refers to the QuInnE (Quality of jobs and Innovation generated Employment outcomes) indicators of quality work, developed during an interdisciplinary, EU funded, study of job quality and innovation (2015-2018). Some of 
these indicators cover a range of heatures of work and employment that represent an appropriate framing device for us, and we have selected the broad categories of Wages, Employment Quality and Work Life Balance as those most relevant to our concerns (see Table 1).

[insert table 1 here]

In examining the elements we have chosen to focus on, we also need to acknowledge their interrelated nature. For example, when considering wages we need to consider general wage levels, but also the security and regularity of work (Sissons, 2011), which obviously influences take home pay and income. Cooper and White (2017) cite TUC figures that show that real wages in the UK have dropped by 10.4 per cent since 2008, and Padley et al. (2017) report a 20 per cent increase in the number of households below the Minimum Income Standard (MIS), a benchmark of income adequacy, between 2008/09 and 2014/15 in the UK. Such figures suggest a deterioration in pay but we must also factor in income inequalities. As Cooper and White (2017) state, income has fallen by 8 per cent for the bottom tenth of the UK household income earners but only 1 percent for the top tenth, reflecting not only declining wages but also the withdrawal of benefits for those on lower incomes.

In their analysis of poverty in Britain, Shildrick et al. (2012) elaborate on this situation by differentiating between low-paid work, low-pay, no-pay cycles, precarious work and poor work. The first is self-explanatory covering those workers on low wages. Low-pay, no-pay refers to workers in 'a longitudinal pattern of employment instability and movement between low-paid jobs and unemployment, usually accompanied by claiming of welfare benefits' (Shildrick et al., 2012: 18). Precarious work is more difficult to define but Shildrick et al. (2012) see it as work that is temporary or of short tenure, and they argue that there is evidence that the prevalence of such work is increasing, and was certainly reported as such by the subjects of their fieldwork. Finally, poor work is that which is poorly paid, insecure and unhealthy but also lacks scope for skill development or progression. Further evidence of precarious or poor work 
is provided by Standing (2011), who argues that temporary work and part-time jobs (the 'gig' economy); supposedly 'self-employed' or subcontractor status employment practices; zerohours contracts, internships and other forms of casualization, are contributing to the emergence of a 'precariat'. This precariat is made up of people in work who nevertheless endure insecurity with regard to their employment status, their job security, their work security, their income, their skill reproduction and workplace representation (Standing 2011). The result of these practices is a proportion of the workforce who experience poverty in work (Lansley and Mack, 2015; Shildrick et al. 2012), inequality (Dorling, 2014, 2018) or stress in their working arrangements. Whilst this situation has typically affected the low skilled and low paid, the precarious nature of work not only extends to white collar and professional work (Standing 2011) but is increasingly becoming normalized (Rubery et al. 2018).

The articles in this special issue allow the exploration of several aspects of the relationship between neoliberalism and work and employment, and offer great insights into the experiences of those who work under neoliberalism in a variety of contexts. The first two articles by Beverly Geesin and Simon Mollan and Rich Moth explore how neoliberal assumptions are mediated through regulatory and policy initiatives, which bring about changes in employment structures and experiences. Geesin and Mollan's articles examines a dispute between Philadelphia Tax Workers Alliance (TWA) of Pennsylvania and the Philadelphia Parking Authority (PPA) the local regulatory body, over a transfer of regulatory responsibility and the subsequent development of an expansive programme of regulation and surveillance. The case demonstrates the role of state organizations in neoliberalism and illustrates the evolution of neoliberal systems but also of forms of resistance against such systems. They conclude that resistance is not futile but increasingly difficult in a context that involves individualized and precarious work, and that battling to maintain collective identities is a significant part of the resistance process. 
Moth's article examines health policy initiatives that have led to the restructuring of statutory service provision in England. Focussing on mental health services, Moth reveals changes to management and organizational practices involving escalating performance management regimes, work intensification and professional deskilling, which disrupt mutually supportive practices amongst practitioners. Further, the changes have cast service users as individualized, 'responsibilized', 'consumers', and, despite policy rhetoric on recovery and service user centred treatment, has reinforced a biomedical model of service provision. However, like Geesin and Mollan, Moth finds scope for resistance amongst the professional staff who work hard to maintain a values-based ethos and progressive practices.

Constantine Manolchev's and Chitalu Kabwe and Smita Trioathi's articles focus rather more on the experiences of workers and how they make sense of those experiences, in starkly different contexts. Manolchev's article, like Geesin and Mollan's and Moth's, examines resistance in the context of neoliberal working regimes. His analysis of the experiences of lowpaid, low-skill employees in hospitality and care reveals the use of sensemaking narratives as a form of 'Self'-defence against management attempts to mould 'appropriate' employees. Firstly, workers evaluate their current experiences against those from earlier in their work histories. Whilst they are aware that their circumstances were precarious, they may still judge them as offering opportunities compared to their previous circumstances. Secondly, workers deploy a narrative of camaraderie, becoming more collectively mobilized by the difficulties of their circumstances. Finally, the third narrative amongst workers is that of gratitude, being appreciative of the opportunities they have to express themselves through work and take pride in that work. Manolchev's article illustrates the ambiguities of precarious work and the feelings of ambivalence amongst those experiencing it, and indicates that the phenomenon of precarity is a complex one.

Kabwe and Trioathi's article examines the experiences of a group of employees who would not usually be considered to be disadvantaged, so-called 'high-potentials' selected to participate in 
corporate talent management training programmes, which they would expect to lead to career advancement. However, as Kabwe makes clear, the experiences of the 'talented' in such programmes suggests they have a good deal in common with other more obviously 'exploited' workers. The programmes imply the corporate ownership of the 'talent' and prioritize the exploitation of this talent above any benefits to participants, who are subject to pernicious forms of organizational control and socialization. The trainees also experienced work intensification and were often required to carry out tasks 'above their pay grade', and then were frustrated in their attempts to advance into more senior roles by a lack of opportunities. The scope to resist these problems was limited, as trainees felt they were in competition with others for advancement and that voicing their dissatisfactions would damage their prospects. Thus, their position is one of weakness and precarity, and their ability to resist is hampered by their perception of high stakes and a lack of collectivity.

The four articles highlight the complexity and reach of the degradation of employment in two ways. Firstly, they tie changes to work and employment to the neoliberal context through regulatory and policy processes. These phenomena, couched in service improvement and consumer protection terms, have little to do with employment directly, but have very clear implications for the restructuring of the labour process and experiences of work, through heightened surveillance, and more intense performance management. It seems, therefore, that we should widen our scrutiny of employment relations beyond the more obvious manifestations of change, such as forms of employment contract, and consider in more detail the potential impact of so-called reforms and improvements for employees. Secondly, the articles demonstrate the extensive reach and impact of neoliberal values and systems into employment and work. This is reflected not just in the projection of neoliberal sensibilities such as 'responsibilization', 'bundles of skills' and 'on-demand' business models into employment and individual personhood, but also in the ways in which managerial and financially-driven technical systems of 'data capitalism' such as targets, KPIs, and performance management infrastructures increasingly serve to structure and govern work activities and the nature of 
workplaces (Aitken, 2017; Beer, 2018). Further consideration of the multiple ways in which neoliberalism is manifested in the workplace through such values and systems is likely to be an important domain where critical research on work, management and organization can be brought into a conversation with writings on political economy, financialization, digitalization and automation.

It is clear that no occupation or profession is immune from the intrusion of these values and systems and the changes they foster (Leicht, 2016; Reed, 2018). Even high-value individuals who might be considered to be favoured within organizations are affected by intensification, exploitation and managerial intrusions into areas that were traditionally domains of autonomy and discretion. Taken together the articles might create a sense of pessimism, and it is difficult to extract positives from the cases our authors have shared. However, to varying degrees, each does indicate the continued appetite for resistance amongst those affected by the neoliberal regimes, and the ways in which such resistance can be mobilized and adapted to meet new challenges.

\section{References}

Adamson M and Roper I (2019) 'Good' jobs and 'bad' jobs: Contemplating job quality in different contexts. Work Employment and Society 33(4): 551—559.

Aitken R (2017) 'All data is credit data': Constituting the unbanked. Competition and Change 21(4): 274-300.

Allan S Faulconbridge J and Thomas P (2019) The fearful and anxious professional: Partner experiences of working in the financialized professional service firm. Work Employment and Society 33(1): 112-130. 
Bacevic J (2019) Knowing neoliberalism. Social Epistemology 33(4): 380 -392.

Becker GS (1964) Human Capital: A Theoretical and Empirical Analysis. Chicago, IL: Chicago University Press.

Beer D (2018) The Data Gaze: Capitalism, Power and Perception. London: Sage.

Braverman H (1974) Labor and Monopoly Capitalism. London: Monthly Review Press.

Chartered Institute for Personnel and Development (2018). Taylor Review: Response to Matthew Taylor's Review of Modern Employment Practices. London: CIPD.

Burawoy M (1979) Manufacturing Consent: Changes in the Labour Process Under Monopoly Capitalism. Chicago, IL: Chicago University Press.

Cooper C and White D (eds) (2017) The Violence of Austerity. London: Pluto.

Department for Business, Energy and Industrial Strategy (2018) Good Work: A Response to the Taylor Review of Modern Working Practices. London: BEIS.

Dorling D (2014) Inequality and the 1\%. London: Verso.

Dorling D (2018) Peak Inequality: Britain's Ticking Timebomb. Bristol: Policy Press.

Ehrenreich B (2005) Bait and Switch. New York: Henry Holt.

Elger T (1991) Task flexibility and intensification of labour in UK manufacturing in the 1980s. In Pollert A (ed.) Farewell to Flexibility? Oxford: Blackwell, pp. 46-66. 
Eurofound (2017) Sixth European Working Conditions Survey - Overview Report (2017 update). Luxembourg: Publication of Office of the European Union.

Fabry A and Sandbeck, S. (2019) Introduction to special issue on 'authoritarian neoliberalism'. Competition and Change 23(2): 109-115.

Fleming P (2017) The human capital hoax: Work, debt and insecurity in the era of Uberization. Organization Studies 38(5): 691-709.

Friedman A. (1977) Industry and Labour: Class Struggle at Work and Monopoly Capitalism. London: Macmillan.

Ghai D. (2003) Decent work: Concept and Indicators. International Labour Review 142(2): $113-145$.

Granter E, Wankhade P, McCann L, Hassard J and Hyde P (2019) Multiple dimensions of work intensity: ambulance work as edgework. Work, Employment and Society 33(2): 280 -297.

Griffin P (2009) Gendering the World Bank: Neoliberalism and the Gendered Foundation of Global Governance. New York: Palgrave.

Harvey D (2005) A Brief History of Neoliberalism. Oxford: Oxford University Press.

Hassard J, McCann L and Morris JL (2009) Managing in the Modern Corporation: The Intensification of Managerial Work in the UK, USA and Japan. Cambridge: Cambridge University Press. 
Jensen MC and Meckling WH (1976) Theory of the Firm: Managerial Behavior, Agency Costs and Ownership Structure. Journal of Financial Economics, 3(4): 305-360.

Kalleberg AL (2016) Good jobs, bad jobs. In Edgell S, Gottfried H and Granter E (eds) The Sage Handbook of the Sociology of Work and Employment. London: Sage, pp.111-128.

Kirk E (2018) The 'problem' with the employment tribunal system: Reform, rhetoric and realities for the clients of Citizen's Advice Bureaux. Work, Employment and Society 32(6): 975-991.

Lansley S and Mack J (2015). Breadline Britain: The Rise of Mass Poverty. London: Oneworld.

Leicht K (2016) Market Fundamentalism, Cultural Fragmentation, Post-Modern Scepticism, and the Future of Professional Work, Journal of Professions and Organization 3(1): 103-117.

Martin E (1994) Flexible Bodies. Boston, MA: Beacon Press.

Mirowski P (2013) Never Let a Serious Crisis Go to Waste. London: Verso.

Moore PV (2018) The Quantified Self in Precarity. London: Routledge.

Padley M, Hirsch D and Valadez L (2017) Households below a Minimum Income Standard: 2008/09-2014/15. York: Joseph Rowntree Foundation.

Plehwe D, Walpen B and Neunhoffer G (eds) (2006) Neoliberal Hegemony: A Global Critique. London: Routledge. 
Reed MI (2018) Elites, professions, and the neoliberal state: critical points of intersection and contention, Journal of Professions and Organization, 5(3): 297-312.

Rubery J, Grimshaw D, Keizer A and Johnson M (2018) Challenges and contradictions in the 'normalising' of precarious work. Work, Employment and Society 32(3): 509—527.

Schultz T (1961) Investment in human capital. The American Economic Review 51: 1-17.

Shildrick T, MacDonald R, Webster C and Garthwaite K (2012) Poverty and Insecurity: Life in Low-Pay, No-Pay Britain. Bristol: Policy Press.

Sissons P (2011) The Hourglass and the Escalator. London: The Work Foundation.

Standing G (2011) The Precariat: The Dangerous New Class. London: Bloomsbury.

Streeck, W. (2014) Buying Time: The Delayed Crisis of Democratic Capitalism. London: Verso.

Styhre A (2014) Management and Neoliberalism. London: Routledge.

Taylor M, Marsh, Nicol D and Broadbent P (2017) Good Work: The Taylor Review of Modern Working Practices. London: Department for Business, Energy and Industrial Strategy.

Thrift N (2005) Knowing Capitalism. London: Sage.

TUC (2018a) Taylor Review: Agency Workers Recommendations. London: TUC.

TUC (2018b) Enforcement of Employment Rights. London: TUC. 
TUC (2018c) Taylor Review: Employment Status. London: TUC.

Urciuoli B (2008). Skills and selves in the new workplace. American Ethnologist 35: 211228.

Wacquant L (2009) Punishing the Poor: the Neoliberal Government of Social Insecurity. London: Duke University Press.

Work Foundation (2016) The Commission on Good Work. London: Work Foundation. 